\title{
UTILIZING LANDSAT-8 SENSOR OPERATIONAL LAND IMAGE DATA FOR HYDROTHERMAL ALTERATION MAPPING WITHIN ANKA SCHIST BELT, NORTHWESTERN NIGERIA
}

\author{
Umaru Aliyu Ohinowi ${ }^{A}$, Kankara Ibrahim Aliyu ${ }^{B}$ \\ Received: October 11, 2020 | Accepted: December 25, 2020 \\ DOI: 10.5937/ZbDght2002127A
}

\begin{abstract}
Exploring for mineral deposits within the Anka Schist Belt involves the use of traditional geological techniques such as geochemical and geophysical studies that are very expensive and time consuming. There is therefore need for a better alternative that will provide accurate and reliable information with cost effective and time efficient solution. This effort seeks to explore the potential of remotely sensed digital data in highlighting mineralized zones through hydrothermal alteration studies. Landsat $8 \mathrm{OLI}$ data covering the investigated area was used to detect and map locations of hydrothermal alterations. Image processing methods used were spectral enhancement, false colour composites, band rationing and Principal Component Analysis. Results of false colour composites of band 5: 7: 3 highlighted generally locations of hydrothermal alterations. Band ratios of 4/2, 6/7 and 6/5 revealed the presence of ferric iron minerals, clay rich minerals and ferrous minerals respectively. Principal Components (PCs) of two sets of images (2, 4, 5, $7 \mathrm{H}$-image and 2, 5,6,7 F-image) depicting iron-oxide and hydroxyl mineral deposits as bright pixels were generated. Colour composite of $H, F$ and $H+F$ images enhanced the location of the mineral deposits, by showing areas of mineralization in dark blue (Fe rich), bright yellow (clay rich) and white (Fe and clay rich areas) pixels. Field coordinates of mining locations were superimposed on the remote sensing generated mineral map. The results were found to be in tune. This study recommends the use of remote sensing and geospatial technology in mineral studies through hydrothermal alteration within the basement complex rocks of Nigeria.
\end{abstract}

Keywords: Band Ratio, Principal Component Analysis, False Colour Composite, Landsat-8 OLI.

A Department of Geology, University of Maiduguri, Nigeria; corresponding author: ualeey@gmail.com

B Department of Geology, Federal University Dutsin-Ma, Katsina State, Nigeria 


\section{INTRODUCTION}

A swift look at the history of establishment of Remote Sensing Technology in Nigeria shows that its development in the nation began in 1972, when the University of Ife (now Obafemi Awolowo University) developed a proposal to the Federal Government of Nigeria with the aim of acquiring data in USA's Earth's observation satellite- LANDSAT-2. The federal government accepted the proposal and submitted it to NASA. The data was acquired, while some positives and negatives were at OAU and at the Regional Remote Sensing facility, Nairobi, Kenya. Between 1975 to 1981 some proposals which contained action-oriented recommendations of concrete steps towards a viable National Remote Sensing program in Nigeria were developed. By individual scientists, the Nigerian Society of Remote Sensing (which was inaugurated in 1980) and in collaboration with Cnada Center for Remote Sensing, the Food and Agricultural Organization (FAO) Rome. The FGN included it in her 1975-1980 third National Development Plan, a budgeted sum of N10, 000, 000 for the establishment of a National Remote Sensing Center. Then, an overseas mission was undertaken to Canada, USA and Brazil, and after expenditure of N250, 000 the allocation was withdrawn. This was then followed by inter and intra ministerial conflicts of interests (Sebastian, 2000).

Besides, Nigeria has enormous mineral resources that are emplaced all over the country, most of which are found in abundance within the schist belts. The schist belts are best developed in the northwest, southwestern and central parts of the country. The schist belts are characterized by metasedimentary and metavolcanics deformed low grade rocks (Fitches et al., 1985) and are predominantly composed of metamorphosed pelitic and semi-pelitic rocks (Ekwueme, 1995) but each belt differs in the amount of such lithologies as conglomerates, greywacke, quartzite, calcareous rocks and volcanic rocks. Turner (1983) and Ajibade et al., (1987) identified and classified eleven main schist belts in the northwestern and north-central parts of Nigeria. The eleven schist belts are the Birnin Gwari, Kushaka, Wonaka, Zuru, Anka, Maru, Malumfashi, Kazaure, Illesha, Igarra and Isenyi-Oyan schist belts (Figure 1).

In northwestern Nigeria, schist belts are known to be highly endowed with minerals such as copper, gold, zinc, lead and chromite (Kudamya et al., 2014; Ibrahim, 2012) Exploring for these deposits involved the use of traditional geological techniques such as geophysical and geochemical techniques which are slow and very expensive. Very litthe is known on the use of remote sensing in carrying out mineral exploration through hydrothermal alteration studies which is fast and cost effective (Kankara, 2019). Hydrothermal alteration, also referred to as wallrock alteration is a general term that encompasses many processes by which rock-forming minerals are altered due to reactions accompanying the flow of heated aqueous fluids along fractures and grain boundaries (Meyer and Remley, 1967; Rose and Burt, 1979; Lentz, 1994; Reed, 1997).

Effort have been made by authors to analyze and interprate remotely sensed hydrothermally altered mineral deposit data through false color composite, band rationing and principal component analysis (Abdelsalam et al.,2000; Bean, 1982; Bodruddoza and Fujitmitsu, 2012). In Nigeria, there has been very little research involving remote sensing techniques for mineral exploration studies. One of the few carried out by (Kudamn- 


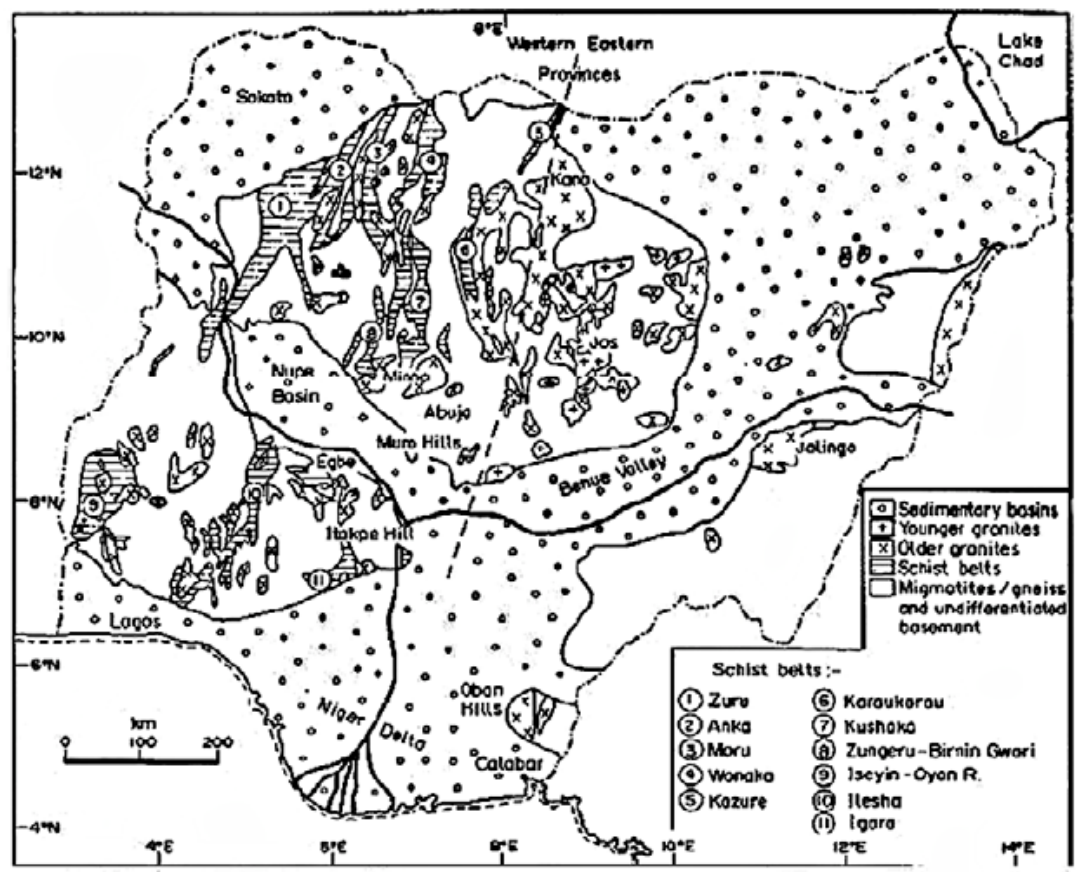

Figure 1. Schist belt locations within the context of the Geology of Nigeria (after Woakes et al., 1987)

yaet.al., 2013) applied band ratio, colur composite to map location of hydrothermal alteration within the Maru schist belt of Northwest Nigeria.

For this reason, this work/research was carried out with the aim of mapping and detecting the distribution of hydrothermally altered mineral deposit zones within the Anka schist belt of Zamfara State, Nigeria.

\section{MATERIALS AND METHODS}

\section{The Study area}

The study area is located within Anka Local Government Area of Zamfara State. It lies between Latitudes $11^{\circ} 58^{\prime} \mathrm{N}$ and $12^{\circ} 15^{\prime} \mathrm{N}$ and Longitudes $5^{\circ} 48^{\prime}$ and $6^{\circ} 00^{\prime} \mathrm{E}$ (Figure 2 ) and covers an area of approximately $770 \mathrm{~km} 2$. It is marked by two distinct weather conditions of rainy and dry seasons. (Climate type and temperature here)

The vegetation of the area is of Sudan Savannah, characterized by abundant short grasses and a few stunted trees and includes acacia, shea butter, baobab and the silk cotton. Elevation ranges from $270-420 \mathrm{~m}$ with the highest point recorded around the eastern part of the study area. 


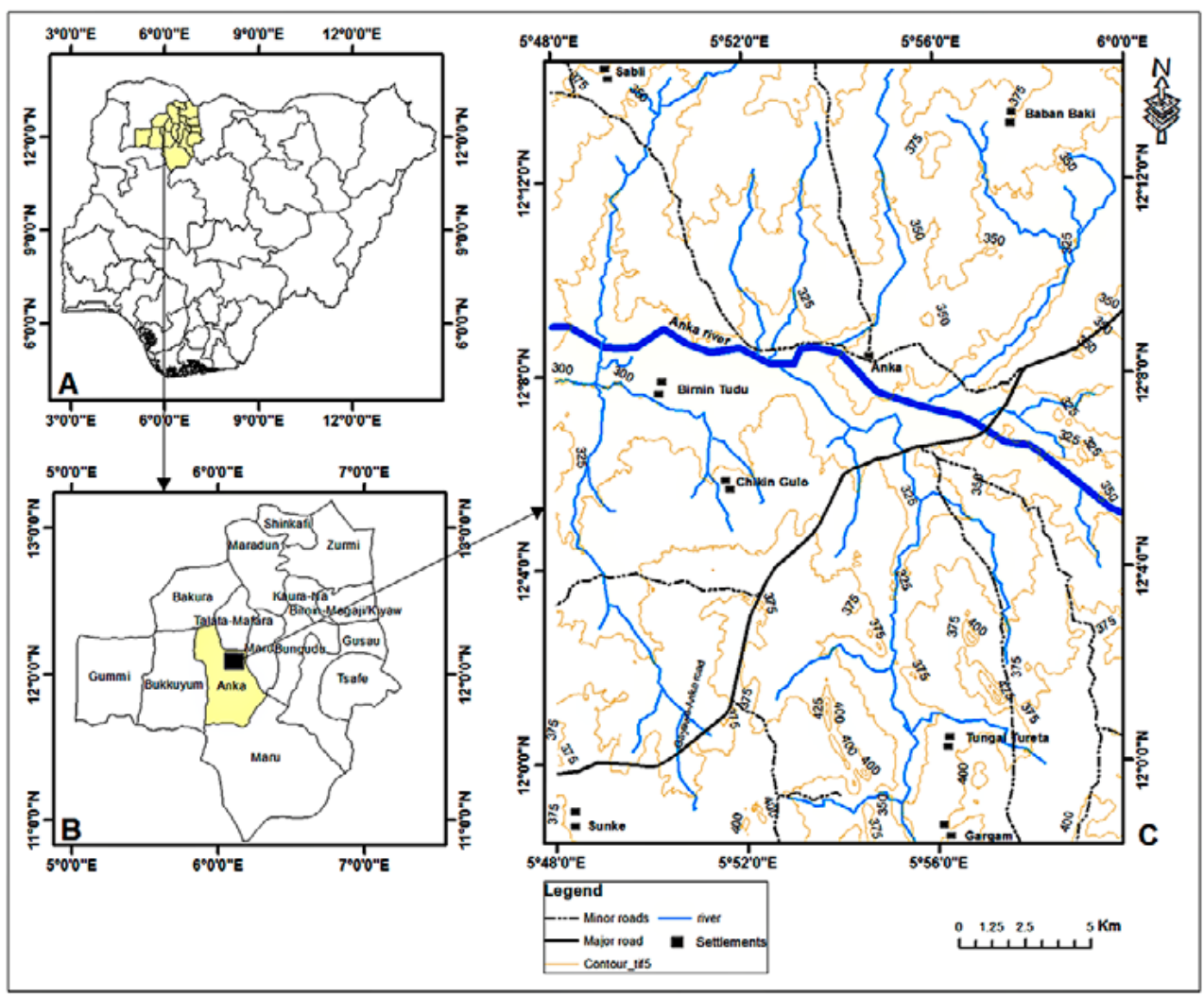

Figure 2. Map of the study area

\section{Geological Context}

Four main lithologies are identified in the area, they are: Schist, medium to coarse grained granites, gneiss and phyllites. Major highlights of the lithological character of the study area are that: In around the Anka area, intense shearing has greatly deformed some of the schist along with other subordinate, with fragments drawn out into flat, occasionally slickensided lenticles (McCurry, 1976).

North of Anka, the schist occurs along the western merging of the acid complex, passing westward into meta-pelites, and interbedded conglomerates which are $15-30 \mathrm{~cm}$. Thick frequently occur up to $400 \mathrm{~m}$ west of the margin. Elsewhere, the Anka area, NNE trending bands of schist are interbedded with other rock units such as: meta-sandstones, purple shales, quartzites, metasiltstones, phylites and grits (McCurry, 1976).

The pebbles in these conglomerates are generally less than $10 \mathrm{~cm}$ long, but fragments which are up to $20 \mathrm{~cm}$ occur composed, mainly of aplogranite and pegmatite which may have been derived from the acid complex and of fine-grained quartzites, sericites, schist and phyllites. In some places, the conglomerates contain virtually no matrix. Generally, the matrixes pellitic in nature. 


\section{Data Collection and Analysis}

\section{Preprocessing of Landsat- $8 \mathrm{OLI}$ data}

Band-ratio images from Landsat 8 OLI image of the study area were produced by dividing the digital number $(\mathrm{DN})$ values of one band by the corresponding $\mathrm{DN}$ values of another band and displaying the new DN values as grayscale image.

Landsat 8 OLI data (2017) covering the study area was subjected to software processing and analysis for the mapping of hydrothermal alterations. Three additive colours (i.e., red, green and blue) were used to display multispectral bands in the colour composite method where the spectral response of the minerals indicates a maximum in their reflectance. This enhancement is achieved by combining bands in the visible and the infrared portion (Crosta and Moore, 1989). (How the data was acquired first)

Landsat-8 OLI image data of the study area was processed using the ENVI (Environment for Visualizing Images) version 5.1 software package. Landsat- 8 data were converted to surface reflectance using the Internal Average Relative Reflection (IARR) method. IARR reflectance technique is recommended for mineralogical mapping as a preferred calibration technique. During the atmospheric correction, raw radiance data from imaging spectrometer is re-scaled to reflectance data. Therefore, all spectra are shifted to nearly the same albedo. The resultant spectra can be compared with the reflectance spectra of the laboratory or filed spectra directly. Panchromatic and cirrus cloud (band 9) bands have not been used in this study. Thermal Atmospheric Correction was performed on TIR bands (Pour and Hashim, 2015).

\section{Image Processing Techniques}

The remote sensing approaches were used on the image in order to show spectral characteristics of the study area for detection of hydrothermal alteration zones. The preparation and enhancement of the image was done by contrast stretching method. This image processing methods are designed to transform multispectral image data format into an image display that either increases contrast between interesting targets and the background or yields information about the composition of certain pixels in the image. False colour composite, band rationing and principle component analysis (Crosta technique) were used in this study.

\section{False Colour Composite}

The display color assignment for any band of a multispectral image can be done in an entirely arbitrary manner. In this case, the color of a target in the displayed image does not have any resemblance to its actual color. The resulting product is known as a false color composite image. There are many possible schemes of producing false color composite images. However, some scheme may be more suitable for detecting certain objects in the image. In this study false colour composite was used to study and detect potential locations of hydrothermal alterations. Bands 5, 7 and 3 (Crosta and Moore, 1989) was assigned to the red, green and blue channel to display areas that are hydrothermally altered. 


\section{Band rationing method}

The band ratio is a technique that has been used for many years in remote sensing to display spectral variations effectively (Goetz et al. 1983). Band rationing is a multispectral image processing method that involves the division of one spectral band by another. This division results in the ratio of spectral reflectance measured in the one spectral band to the spectral reflectance measured in another spectral band. This data was downsampled.

Band ratios are very useful for highlighting certain features or materials that cannot be seen in the raw bands (Inzana et al., 2003).This tends to enhance spectral differences and suppress illumination (topographical) differences. Ratios can be used to differentiate objects if those objects have characteristic spectra. Band rationing for hydrothermal alteration mapping was carried out using ENVI 5.1 software, were all the Landsat ETM+ bands was imported into the ENVI 5.1 environment and band rationing will be carried out.

The band rationing is expressed mathematically as:

$B V_{i, j, r}=\frac{B V_{i, j, k}}{B V_{i, j, l}} \ldots \ldots . .$. Formula adapted from (Kudamnya, 2014)

Where:

- $B V_{i, j, r}=$ output ratio for the pixel at row ${ }_{i}$ and column ${ }_{j} ; B V_{i, j, r}$, has a DN value ranging from 0 to 225 .

- $B V_{i, j, k}=$ brightness value at the same location in band $\mathrm{k}$

- $B V_{i, j, l}=$ brightness value in band

\section{Principal component analysis}

In addition to band ratios, principal component analysis was applied to get satisfactory results about the alteration zones. PCA is an important technique that provides simple information of multispectral datasets. It is effective for spectral enhancement and information manipulation. This analysis was carried out using ENVI 5.1 software. For this study, selective principal component analysis (Crosta Technique) was applied to Landsat 8 OLI imagery in order to map for argillites and iron stain areas (Crosta, 1989). Using this technique an image displaying clay alteration as light tone ( $\mathrm{H}$ - Image), was produced by applying principal component analysis to bands 2, 5, 6, 7 and negating the resulting principal component image. Also, an image displaying variation in iron oxide (F- Image) was produced by applying principal component analysis on bands 2, 4, 5, 6 and negating the resultant principal component image. Production of $\mathrm{H}$ and $\mathrm{F}$ image was followed by combination of the $\mathrm{H}$ and $\mathrm{F}$ to generate an image displaying clay and iron oxide as light tone $(\mathrm{H}+\mathrm{F})$ image. The resultant $\mathrm{H}, \mathrm{H}+\mathrm{F}$ and $\mathrm{F}$ image was assigned to the red, green and blue channels. This image is expected to display iron stain and argillite rich areas as white pixels, more argillite than iron stain areas as bright reddish to orange pixels andmore argillite than iron stain areas as bright cyan to bluish pixels. 


\section{RESULTS AND INTERPRETATIONS}

\section{Color Models}

Color models are systems that allow for the creation of a range of colors from a short list of primary colors. Color models can be additive or subtractive. Additive color models combine emitted light to display color variations and are commonly used with computer monitors, televisions, scanners, digital cameras, and video projectors (Kankara, 2018). The RGB (red-green-blue) color model is the most common additive The RGB model combines light beams of the primary hues of red, green, and blue to yield additive secondary hues of magenta, cyan, and yellow. Although there is a substantive difference between pure yellow light $(\sim 580 \mathrm{~nm})$ and a mixture of green and red light, the human eye perceives these signals as the same. The RGB model typically employs three 8-bit numeric values (called an RGB triplet) ranging from 0 to 255 to model colors.

\section{False Color Composite}

Although a high-quality map is composed of many different elements, color is one of the first components noticed by end-users. This is partially due to the fact that we each have an intuitive understanding of how colors are, and should be, used to create an effective and pleasing visual experience. Nevertheless, it is not always clear to the map-maker which colors should be used to best convey the purpose of the product. This intuition is much like listening to our favorite music. It is known when a note is in tune or out of tune, but we wouldn't necessarily have any idea of how to fix a bad note. Color is indeed a tricky piece of the cartographic puzzle and is not surprisingly the most frequently criticized variable on computer-generated maps

This section attempts to outline the basic components of color and the guidelines to most effectively employ this important map attribute.

Figure 3 shows hydrothermal alteration areas (ferric and clay alteration) in purple colour false colour composites (RGB) of bands 5:7:3. Statistical analysis of the area of coverage of hydrothermal alterations shows that hydrothermally altered areas amount to $89.779 \%\left(616.32 \mathrm{~km}^{2}\right)$ of the entire study area (Table 1$)$.

Table 1: Area coverage of hydrothermal alterations in False color composite

\begin{tabular}{|l|r|r|r|}
\hline Minerals & \multicolumn{1}{|c|}{ Count } & \%count & \multicolumn{1}{c|}{ Area $\left(\mathrm{Km}^{2}\right)$} \\
\hline Ferric and hydrous minerals & 456913 & 89.779 & 616.32 \\
\hline Others & 52016 & 10.220 & 70.17 \\
\hline Total & 508929 & & 686.49 \\
\hline
\end{tabular}




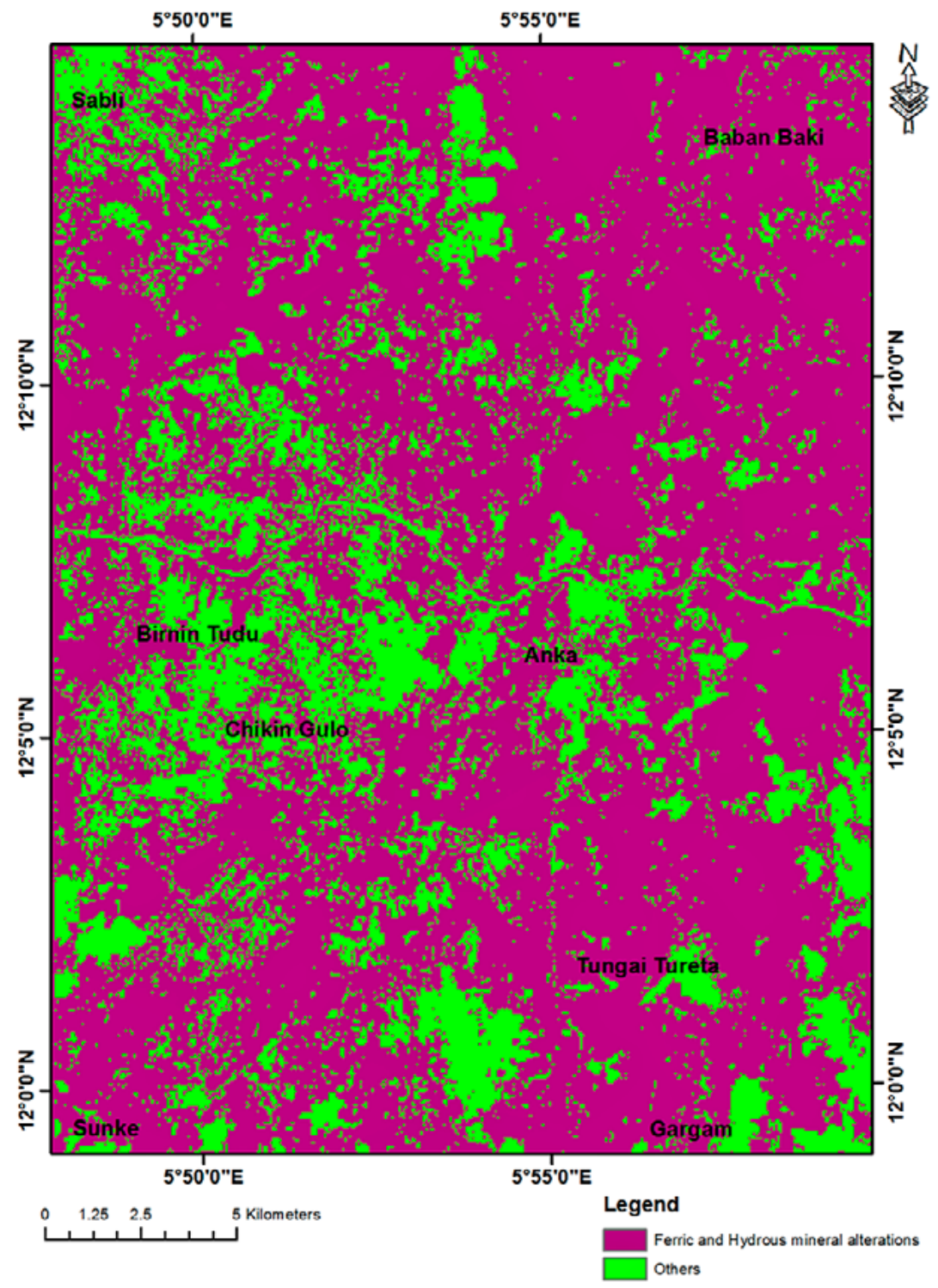

Figure 3. Bands 5:7:3 color composite of Landsat $8 \mathrm{OLI}$ 


\section{Band rationing}

Band ratio (BR) transformation was used for qualitative detection of hydrothermal alteration minerals.

Band ratio $4 / 2$ highlighted areas in which any ferric iron mineral occurs pervasively or as coatings and are indicated as bright pixels they occur mostly in the northeastern and northwestern parts of the study area (Figure 5) this is because iron bearing minerals have high reflectance in Landsat 8 OLI band 4 and high absorption in band 2. In (Figure 6) band ratio 6/7 depicted hydroxyl bearing minerals due to hydroxyl's high reflectance in band 6 and absorption band 7, they occur mostly in the southern and southwestern parts of the study area. The high value of band 6/7 ratio appears in light tone due to the high content of hydroxyl-bearing minerals. The ratio 6/5 (Figure 4) was used for mapping ferrous minerals due to the high reflectance and absorbance of these minerals in this ratio. They mostly occur in the western parts of the study area. Band ratiosof OLI (6/7, 6/5 and 4/2) and their combinations in RGB sequence as color composite (FCC) image using Sabins (1999) approach were created for the detection of hydrous minerals (clay minerals) and iron-rich zones in blue and red coloured pixels (Figure 7). Statistical analysis of the area of coverage of the hydrothermal alterations shows that areas of hydrous minerals amount to $4.072 \%\left(28.36 \mathrm{~km}^{2}\right)$, areas with ferric minerals cover $72.101 \%\left(494.56 \mathrm{~km}^{2}\right)$ of the entire study area (Table 2$)$

Table 2. Statistics of hydrothermal alterations in band rationing

\begin{tabular}{|l|r|r|r|}
\hline Minerals & \multicolumn{2}{|c|}{ Count } & \multicolumn{2}{|c|}{ \% count } & \multicolumn{1}{c|}{ Area $\left(\mathrm{Km}^{2}\right)$} \\
\hline Hydrous minerals & 20721 & 4.072 & 28.36 \\
\hline Others & 121263 & 23.827 & 163.57 \\
\hline Ferric minerals & 366945 & 72.101 & 494.56 \\
\hline Total & 508929 & & 686.49 \\
\hline
\end{tabular}




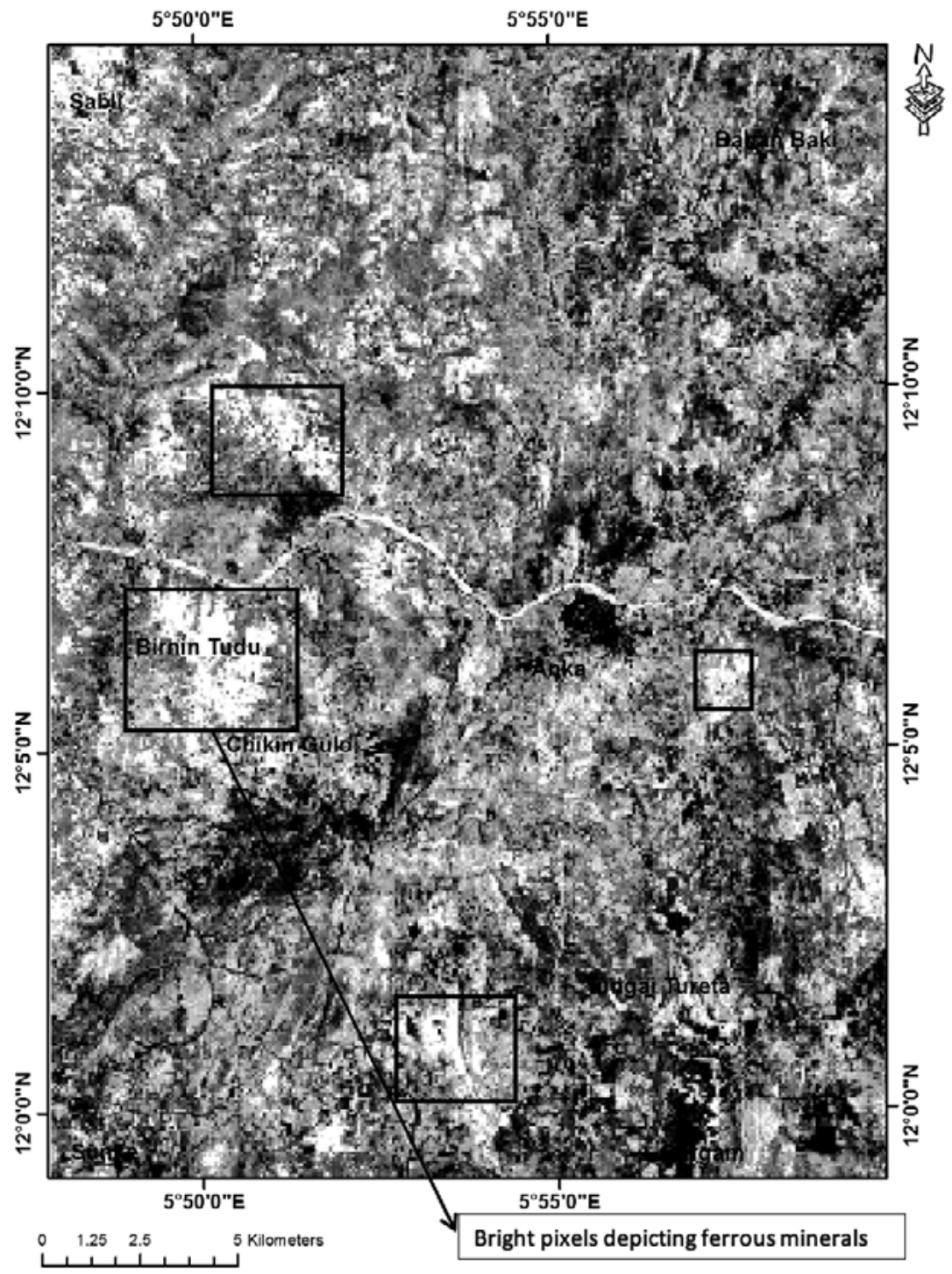

Figure 4: Map depicting areas with abundant ferrous minerals (band ratio 6/5) 


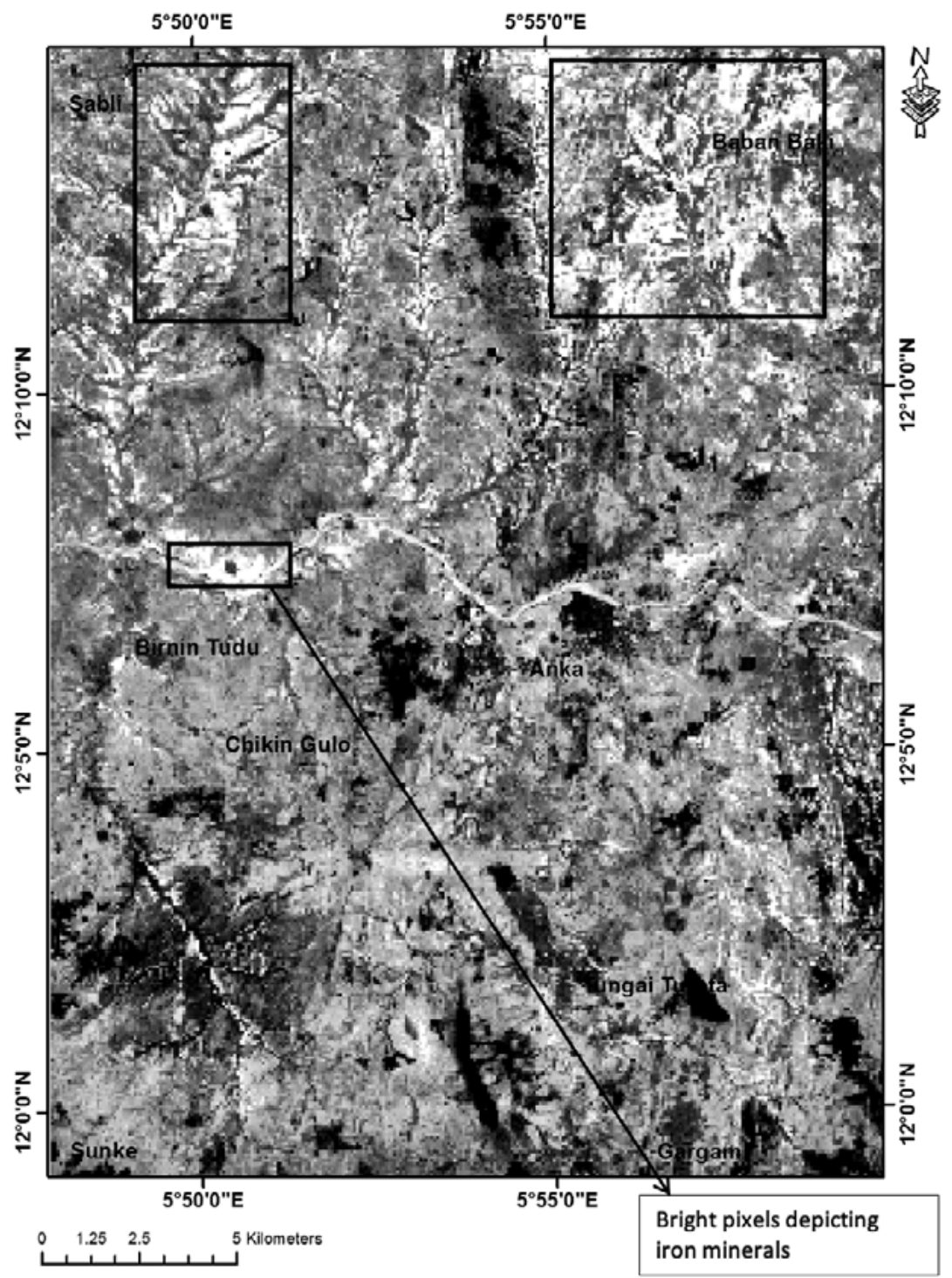

Figure 5: Map depicting areas with abundant ferric minerals (band ratio 4/2) 


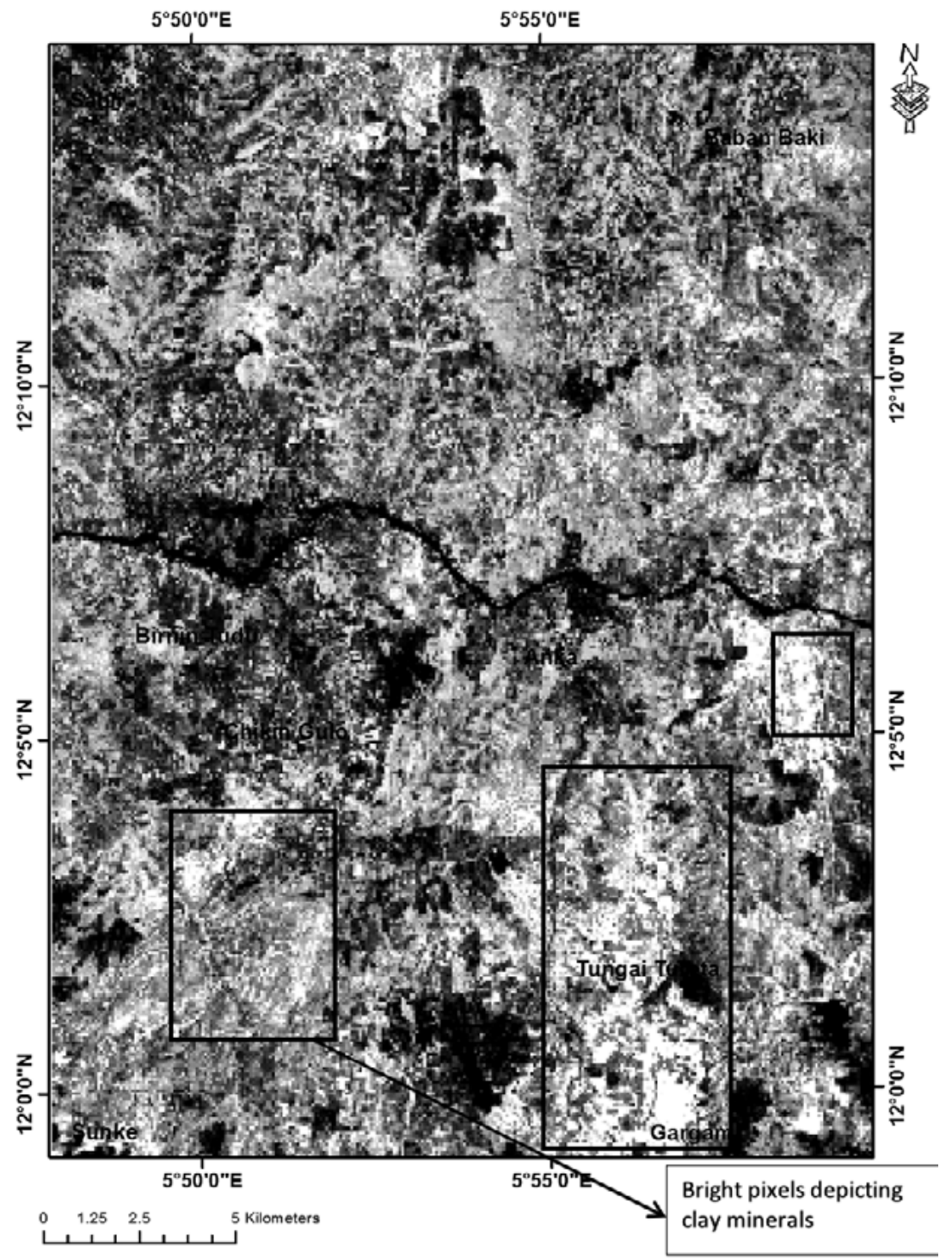

Figure 6: Map depicting areas with abundant clay minerals (band ratio 6/7) 


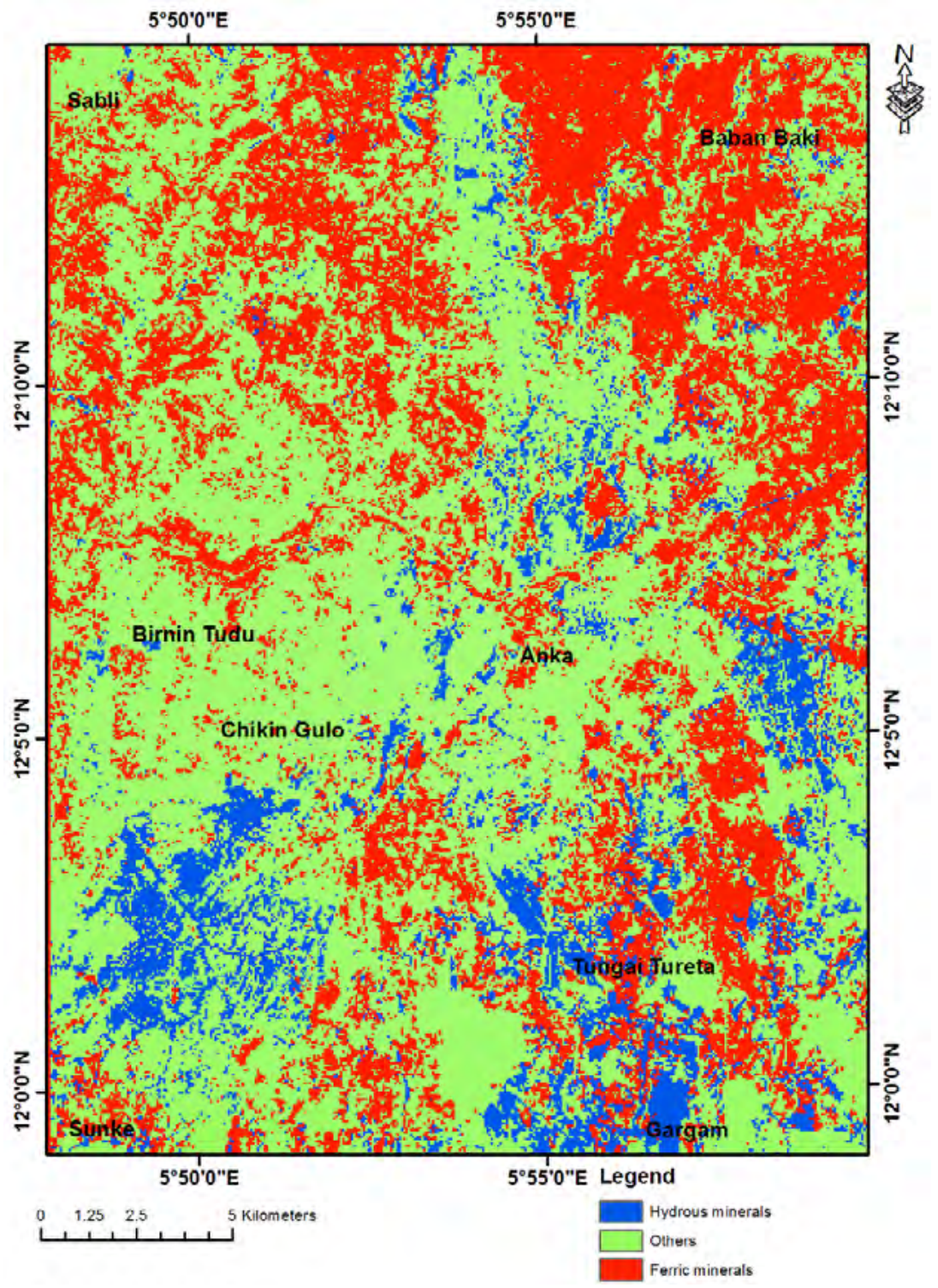

Figure 7: Band ratios $(4 / 2,6 / 5,6 / 7)$ in RGB combinations 


\section{Principal Component Analysis}

In addition to band ratios, PCA was applied to the acquired Landsat 8 data to get satisfactory results about the alteration zones. It was utilized to minimize the redundancy of information that exists between the different bands. The Feature-oriented Principal Components Selection (FPCS), which depends on the examination of PCA eigenvector loadings to decide which of the principle component images, allowed concentrating data immediately concerning with the theoretical spectral signatures of the mineral of interest. The pertinent principal component images show targeted areas in bright or dark pixels. Using PCA technique, the $\mathrm{OH}$-bearing minerals and iron-rich mineral was extracted by transforming the selected bands into their principal components. In order to delineate alteration areas of $\mathrm{OH}$ bearing minerals (H-image), selected bands $2,5,6$, and 7 were transformed using PCA (Table 3) to delineate zones rich in OH-bearing minerals (H-image).

Examining the eigenvector values of the PCA loading of the selected four bands 2, 5, 6 , and 7, demonstrate that PC 3 showed a clear contrast between bands $6(-0.754830)$ and $7(0.257948)$ (Table 3). Thus, PC3 highlighted the alteration areas in dark tone as a perfect contrast between eigenvectors of bands 6 and 7. The PC 3 was negated to produce $\mathrm{H}$ image (OH-bearing minerals) (Figure 8).

Likewise, applying PCA to the selected bands 2, 4, 5, and 6 to delineate zones of richer iron oxides, revealed that the PC4 (Table 4 ) has a good contrast between the eigenvectors of band $2(0.911463)$ and band $4(-0.407988)$ and allowed for delineating areas of higher iron-oxides content (F-image) after negating PC4 (Figure 9). This was followed by the combination of the $\mathrm{H}$ and $\mathrm{F}$ image to produce and image that shows all the altered areas in bright tones (Figure 10).

After obtaining $\mathrm{H}, \mathrm{F}$ and $\mathrm{H}+\mathrm{F}$ images in a grey scale, a color composite image "Crosta alteration image" was generated after utilizing the $\mathrm{OH}$-bearing minerals (H-image) in the red channel, the iron-bearing oxides (F-image) in the blue channel and the $\mathrm{H}+\mathrm{F}$ image in green. The alteration zones resulting from this combination is shown in (Figure 11). It is clear from the principal component analysis map that the iron-oxide deposits are abundant within the north-northeastern parts of the study area where basement rocks are abundant while the clay minerals are most abundant in the southeastern parts of the study area. Thus, the alteration zones were shown in dark blue, bright yellow and whitish colors respectively.

Statistical analysis of the area of coverage of the hydrothermal alterations shows that areas of ferric minerals amount to $71.734 \%\left(492.45 \mathrm{~km}^{2}\right)$, areas with both ferric and hydrous minerals cover $8.304 \%\left(57 \mathrm{~km}^{2}\right)$ while areas of hydrous minerals cover $3.374 \%$ $\left(23.16 \mathrm{~km}^{2}\right)$ of the entire study area (Table 5). 
Table 3: PCA of the selected bands 2, 5, 6 and 7 of Landsat 8

\begin{tabular}{|c|r|r|r|r|}
\hline Eigenvector & \multicolumn{1}{|c|}{ Band 2 } & \multicolumn{1}{c|}{ Band 5 } & \multicolumn{1}{c|}{ Band 6 } & \multicolumn{1}{c|}{ Band 7 } \\
\hline PC1 & 0.187935 & 0.454044 & 0.553223 & 0.672658 \\
\hline PC2 & 0.122956 & 0.720770 & 0.169975 & -0.660667 \\
\hline PC3 & 0.505989 & 0.328129 & -0.754830 & 0.257948 \\
\hline PC4 & 0.832789 & -0.408248 & 0.308681 & -0.210981 \\
\hline
\end{tabular}

Table 4: PCA of the selected bands 2, 4, 5 and 6 of Landsat 8

\begin{tabular}{|c|r|r|r|r|}
\hline Eigenvector & \multicolumn{1}{|c|}{ Band 2 } & \multicolumn{1}{c|}{ Band 4 } & \multicolumn{1}{c|}{ Band 5 } & \multicolumn{1}{c|}{ Band 6 } \\
\hline PC1 & 0.214555 & 0.532345 & 0.555789 & 0.601393 \\
\hline PC2 & -0.054581 & -0.219349 & -0.599569 & 0.767740 \\
\hline PC3 & 0.346732 & 0.708548 & -0.573558 & -0.220834 \\
\hline PC4 & 0.911463 & -0.407988 & 0.051454 & -0.011583 \\
\hline
\end{tabular}

Table 5. Statistics of hydrothermal alterations in PCA

\begin{tabular}{|c|c|c|c|}
\hline Minerals & Count & $\%$ count & Area $(\mathrm{Km} 2)$ \\
\hline Ferric minerals & 365075 & 71.734 & 492.45 \\
\hline Ferric and hydrous minerals & 42259 & 8.304 & 57.00 \\
\hline Hydrous minerals & 17172 & 3.374 & 23.16 \\
\hline Others & 84423 & 16.588 & 113.88 \\
\hline Total & 508929 & & 686.49 \\
\hline
\end{tabular}




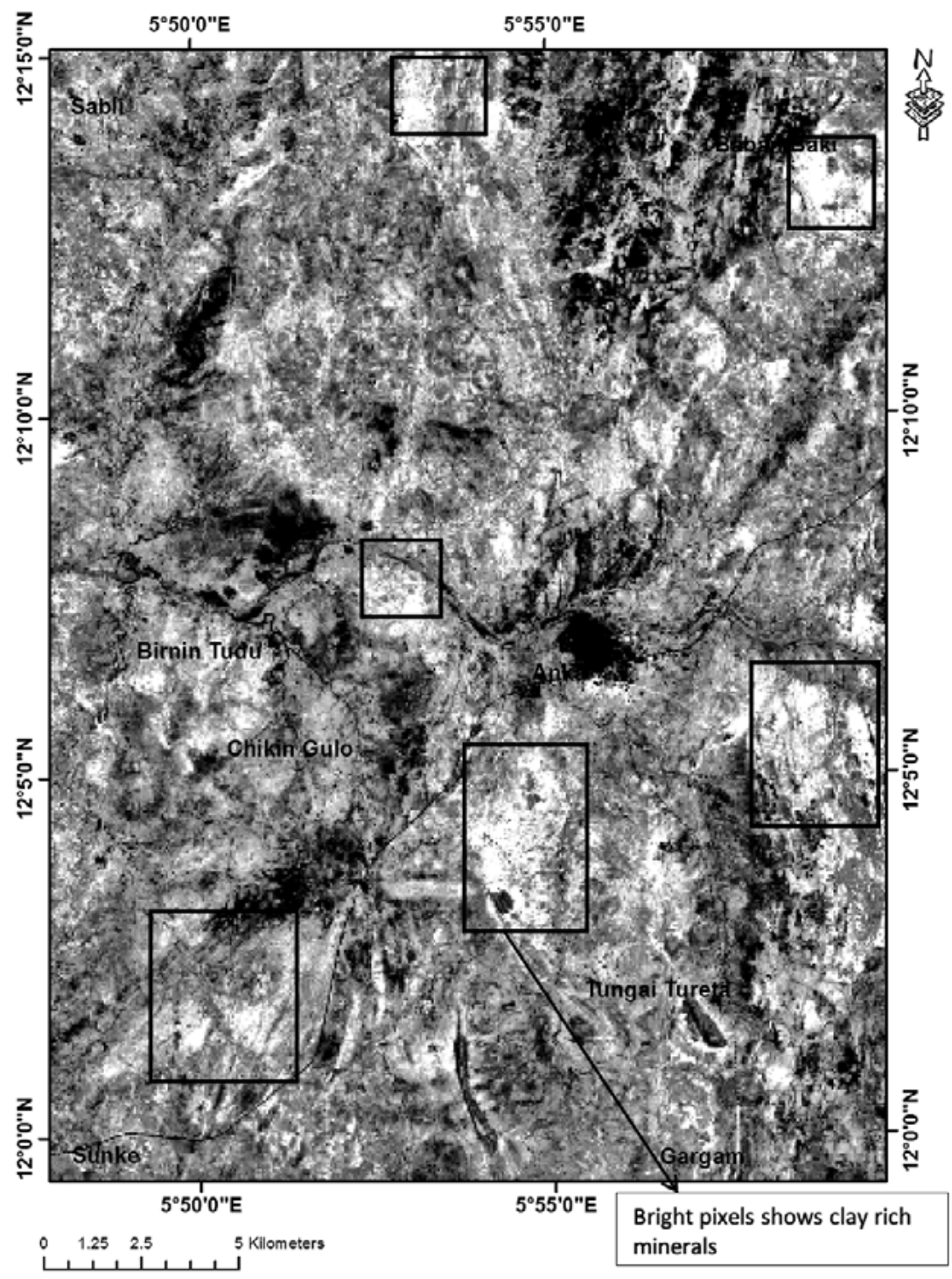

Figure 8: $\mathrm{PC} 3$ negative of PCA 2, 5, 6 and 7 representing hydroxyl mineral (H-image). 


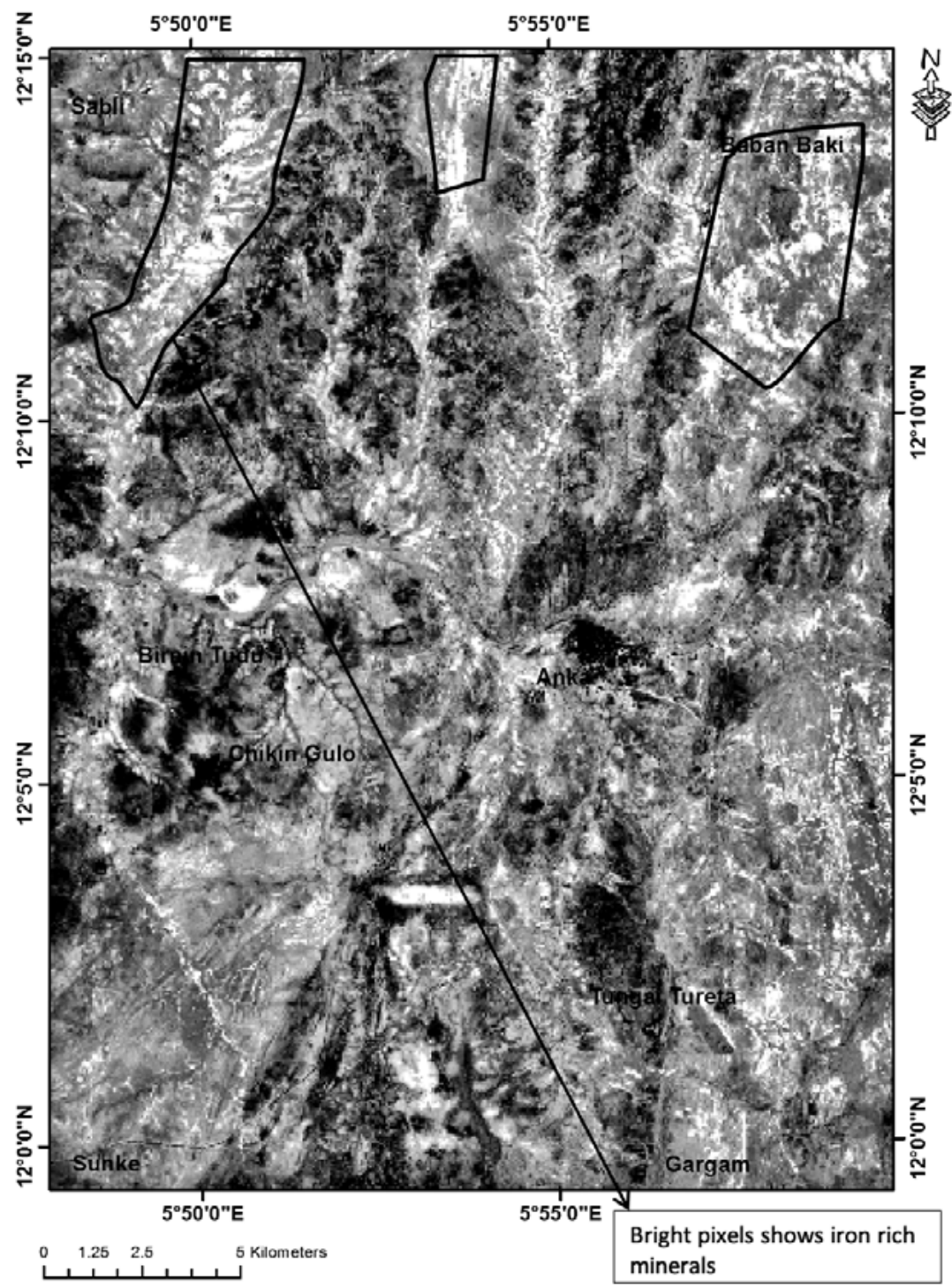

Figure 9: PC4 negative of PCA 2, 4, 5 and 6 representing Iron mineral (F-image) 


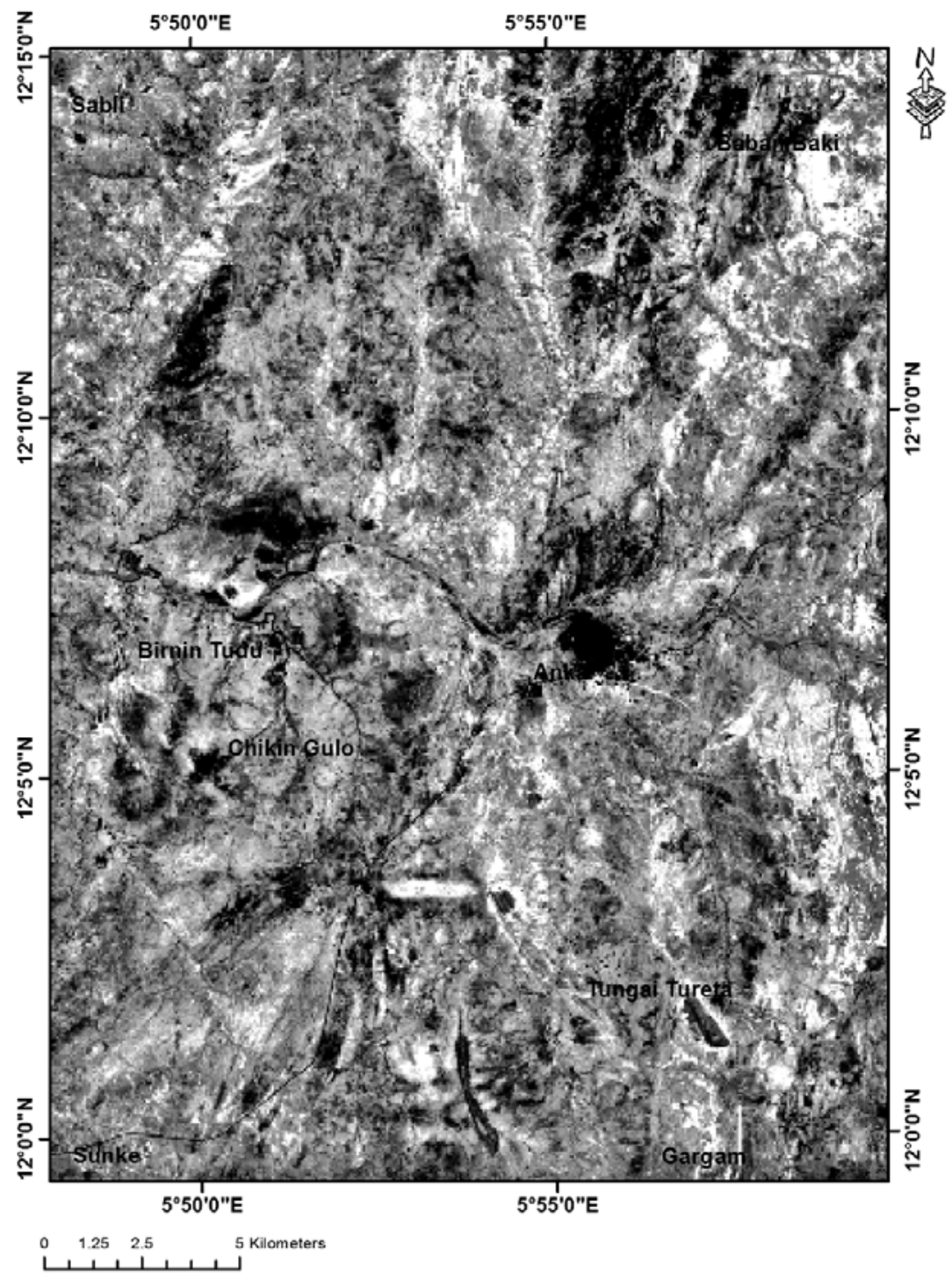

Figure 10: Combinations of PC3 and PC4 negatives ( $\mathrm{F}+\mathrm{H}$-image) 


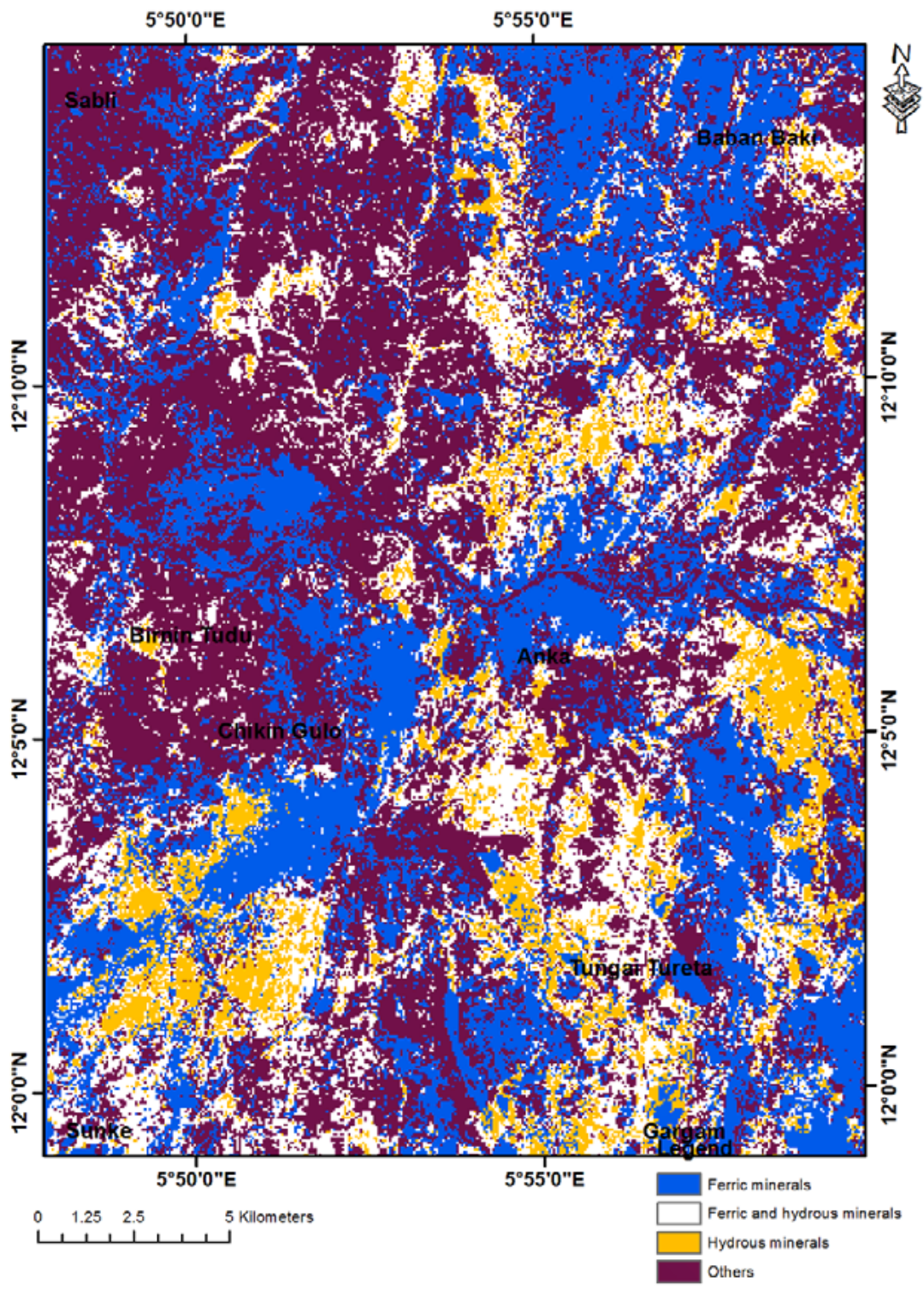

Figure 11: Mineral map of the study area composite of $\mathrm{H}, \mathrm{F}$ and $\mathrm{H}+\mathrm{F}$ images 


\section{Ground truth verification}

In order to evaluate the Landsat 8 OLI satellite data, discriminate alteration zones through field checks were verified. In almost all cases, the fieldwork confirmed in showing real alteration by the interpreted remote sensing imagery. There is a correlation between corresponding mineral deposits location on the satellite image and those observed on the field.

The mineral deposits were emplaced in veins, pegmatite and on surfaces of rocks. It was observed that the minerals identified were mostly copper in which at the time of the ground truthing exercise, they were mined by artisanal miners.

\section{DISCUSSION AND CONCLUSION}

When the Canada Geographic Information System (CGIS) (Ikpokonte, 1993) was developed it was to serve one specific purpose: to calculate the areas of irregularly shaped features, and to present the results in tabular, numeric form. To do this, a number of historic breakthroughs had to be made. Moreso, it is believed that Landsat- 8 can still go long way to serve other purposes in mineral and environmental explorations in Nigeria.

To do that, a map scanner had to be built, software had to be designed to perform tasks that computers had never performed before, and methods had to be found to represent geographic features as linear strings of binary digits on magnetic tape. Just like the way how within a decade the entire Cartographic process had migrated to digital media, and today it is rare to find any part of the process being conducted manually or in analogue. Swift progress is being observed.

For instance, by the 1970s, breakthroughs in Landsat development had paved way for the management and manipulation of many forms of geographic data, and for the Cartographic production process to begin a slow migration to three (3) digital media. Just as word processors allow easy editing of digital text, so Cartographers welcomed the ability of digital media to support rapid editing, and to perform the complex numeric operations involved in map projections.

The studies have mapped successfully the spatial distribution mineralization. So, it is quite clear that all these methods are quite efficient to delineate hydrothermal alteration products using Landsat 8 OLI data and geospatial technology.

After using the conventional alteration mapping methods on the Landsat 8 OLI image of the study area, it showed that the colour composite and band ratio methods reflected their efficiency to define the area of hydrothermal alteration. Principal component analysis illustrated the iron-oxides and hydroxyl altered minerals areas. 


\section{REFERENCES}

Ajibade, A.C., Woakes, M., Rahaman, M.A. (1987). Proterozoic crustal development in the Pan-African regime of Nigeria. In: Krooner, A. (Ed.), Proterozoic Crustal Evolution. Geodyn. Ser., Am. Geophysics Union, 17: pp. 259-271.

Beane, R.E. (1982). Hydrothermal alteration in silicate rocks, southwestern North America. In: Titley, S. R. (Ed.), Advances in Geology of the Porphyry Copper Deposits, Southwestern North America, Chapter 6. Tucson: University of Arizona Press.

Bodruddoza, M., Fujitmitsu, Y. (2012). Mapping hydrothermal altered mineral deposits using Landsat 7 ETM+ image in and around Kuju volcano, Kyushu Japan. Journal of Earth System Science, 121, 1049-1057.

Crosta, A., Moore, P. (1989). Enhancement of Landsat Thematic Mapper imagery for residual soil mapping in SW Minas Gerais State Brazil: a prospecting case history in greenstone belt terrain. Proceedings of the 9th Thematic Conference on Remote Sensing for Exploration Geology, Calgary (Ann Arbor, MI: Environmental Research Institute of Michigan), pp. 1173-1187.

Ekwueme, B.N. (1995). Petrogenesis of Schist in Southeast Lokoja, Central Nigeria. Journal of Pure and Applied. Science, 1, 70-83.

Fitches, W.R., Ajibade, A.C., Egbuniwe, L.G., Holt, R.W., Wright, J.B. (1985). Late Proterozoic schist belts and plutonism in NW Nigeria. Journal of Geological Society, 142, 319-337.

Goetz, A.F.H., Rock, B.N., Rowan, L.C. (1983). Remote sensing exploration: an overview, Economic Geology, 78, 573-590.

Ikpokonte, E. A. (1993). Photogeology and Data Application (400 Level Lecture Notes). Ahmadu Bello University Zaria: Department of Geology.

Inzana, J., Kusky, T., Higgs, G., Tucker, R. (2003). Supervised classifications of Landsat TM band ratio images and Landsat TM band ratio image with radar for geological interpretations of central Madagascar. Journal African Earth Sciences, 37, 59-72.

Kankara, I. A. (2013). Monitoring Natural Resources Using Remote Sensing Techniques: Current Situation in Kaduna and Katsina States, Nigeria. International Journal of Advances in Electronics and Electronic Engineering, 3, 1, 31- 40.

Kankara, I. A. (2018). Masters' Degree Lecture notes on Principles of Cartography, 2017/2018 Session. Department of Geography, Federal University Dutsin-Ma, Katsina State.

Kankara, I. A. (2019). Towards Integrating the Barrier between GIS and Cartography: Applications in $21^{\text {st }}$ Century in Low-Technology Based Nigeria. Annals of Geographical Studies, 2, 4, 14-21.

Kudamnya, E. A., Andongwa, W. T., Osumeje, J. O. (2014). Hydrothermal Mapping of Maru Schist Belt, North-Western Nigeria Using Remote sensing Technique. International journal of civil engineering, 3, 1, 59-69.

Lentz, D. R. (1994). Alteration and alteration processes associated with ore-forming systems. Geological Association Canada, Short Course Notes 11,467

Meyer, C., Remley, J. J. (1967). Wall rock alteration in Geochemistry of Hydrothermal Ore Deposits. New York: Holt, Rinehart and Winston, pp. 166-235. 
Mc Curry, P. (1976). A General Review of The Geology of The Precambrian To Lower Paleozoic Rocks of Northern Nigeria, A Review. In: Kogbe, C. A. (Ed.), Geology of Nigeria. Ibadan: Elizabeth Pub. Co., pp 13-37.

Pour, A. B., Hashim, M. (2015). Hydrothermal alteration mapping from Landsat- 8 data, Sar Cheshmeh copper mining district, south-eastern Islamic Republic of Iran. Journal of Taibah University for Science, 9, 2, 155-166.

Rose, A. W, Burt, D. M. (1979). Hydrothermal alteration in Geochemistry of Hydrothermal Ore Deposits, 3rd edition. New York: John Wiley and Sons, pp. 173-235.

Reed, M. H. (1997). Hydrothermal alteration and its relationship to ore fluid composition, in Geochemistry of Hydrothermal Ore Deposits, 3rd edition. New York: John Wiley and Sons, pp. 303-65.

Sabins, F. F. (1999). Principles and Interpretation, In: Freeman, W. H. (Ed.), Remote Sensing. New York, pp. 494.

Sebastian, P. (2000). Space Science and Technology in Nigeria to date. An MSc Degree student's lecture notes, Kano: Bayero University, Department of Geography.

Turner, D. C. (1983). Upper Proterozoic schist belts in the Nigerian sector of the Pan-African Province of West Africa. Prec. Res. 21, 5-79.

\section{CONFLICTS OF INTEREST}

The authors declared no potential conflicts of interest with respect to the research, authorship, and/or publication of this article.

(c) 2020 by the authors. This article is an open access article distributed under the terms and conditions of the Creative Commons Attribution (CC BY) license (http://creativecommons.org/licenses/by/4.0/). 
